Foss. Rec., 21, 285-290, 2018

https://doi.org/10.5194/fr-21-285-2018

(C) Author(s) 2018. This work is distributed under

the Creative Commons Attribution 4.0 License.

\title{
A giant mite in Cretaceous Burmese amber
}

\author{
Jason A. Dunlop ${ }^{1}$, Konrad Frahnert ${ }^{2}$, and Joanna Mąkol ${ }^{3}$ \\ ${ }^{1}$ Museum für Naturkunde, Leibniz Institute for Evolution and Biodiversity Science, \\ Invalidenstrasse 43, 10115 Berlin, Germany \\ 2 private address: Maxim-Gorki Str. 15a, 14513 Teltow, Germany \\ ${ }^{3}$ Department of Invertebrate Systematics and Ecology, Wrocław University of Environmental and Life Sciences, \\ Kożuchowska 5B, 51-631 Wrocław, Poland
}

Correspondence: Jason A. Dunlop (jason.dunlop@mfn.berlin)

Received: 25 July 2018 - Revised: 2 October 2018 - Accepted: 8 October 2018 - Published: 23 October 2018

\begin{abstract}
An unusually large acariform mite is described as Immensmaris chewbaccei gen. et sp. nov. from the Cretaceous (ca. $100 \mathrm{Ma}$ ) Burmese amber of Myanmar. With an idiosoma plus gnathosoma more than a centimetre long, it represents the largest unequivocal fossil mite ever recorded and approaches the maximum size of the largest living Acariformes today. Although some details of the dorsal idiosoma are equivocal, the new fossil appears to belong to Smarididae (Prostigmata: Parasitengona: Erythraeoidea) and also represents the largest erythraeoid mite ever discovered, indicating a clade of giant, possibly arboreal, mites in the Late Cretaceous of southeastern Asia.
\end{abstract}

\section{Introduction}

Acariform mites (Arachnida: Acariformes) are usually characterized by their small size and have idiosoma lengths, excluding the legs, typically in the 300-500 $\mu \mathrm{m}$ range (Walter et al., 2009). A few reach body lengths of several millimetres. Fully engorged ticks can be even larger but belong to a different order, Parasitiformes. The largest living acariform is the giant velvet mite Dinothrombium tinctorium (Linnaeus, 1767) (Parasitengona: Trombidiidae), which has been reported with idiosoma lengths up to $14 \mathrm{~mm}$ (Thor and Willmann, 1947). Several Australian species presently assigned to Microtrombidiidae and Trombidiidae (Parasitengona: Trombidioidea) have idiosomas reaching 4-6 mm (e.g. Hirst, 1928a, b). Erythraeid mites (Parasitengona: Erythraeidae) are typically in the $1-2 \mathrm{~mm}$ range, which is still quite large by mite standards, but a few Australian taxa are even bigger. Rainbowia imperator (Hirst, 1928) was described with an idiosoma length of $2.5 \mathrm{~mm}, R$. celeripes (Rainbow, 1906) at $3.8 \mathrm{~mm}$ and Erythrites reginae (Hirst, 1928) at $3.2 \mathrm{~mm}$ (Hirst, 1928a; Womersley, 1934; Southcott, 1946). A fossil erythraeid with a body length of $4.6 \mathrm{~mm}$ was described from the Early Cretaceous (ca. $115 \mathrm{Ma}$ ) Crato Formation of Brazil by Dunlop (2007).

Here, we describe a new Cretaceous mite (Figs. 1-2) from the slightly younger (ca. 100 Ma) Burmese amber of Myanmar in southeastern Asia. The most remarkable aspect is its size, with a total body length (excluding the legs) of more than a centimetre. Although the dorsal idiosoma is not well preserved, the general habitus suggests affinities with Smarididae (Erythraeoidea). This discovery is significant as it is both the largest fossil acariform mite assignable to a family group and, by some margin, the largest erythraeoid ever recorded.

\section{Material and methods}

\subsection{Material studied}

The mite originates from the collection of Patrick Müller (Käshofen), no. BUB305, and has now been deposited in the fossil arthropod collection of the Museum für Naturkunde Berlin under the repository number MB.A. 4267 for $\mathrm{Mu}-$ seum Berlin Arthropoda. It is preserved in an approximately teardrop-shaped piece of amber with maximum dimensions of $40 \times 20 \times 7 \mathrm{~mm}$. Syninclusions are an unidentified harvestman and one or more insect larvae. A further, less wellpreserved example of a possibly conspecific large mite was also seen in the private Burmese amber collection of Jörg Wunderlich (Ekaterina A. Sidorchuk, personal communica- 


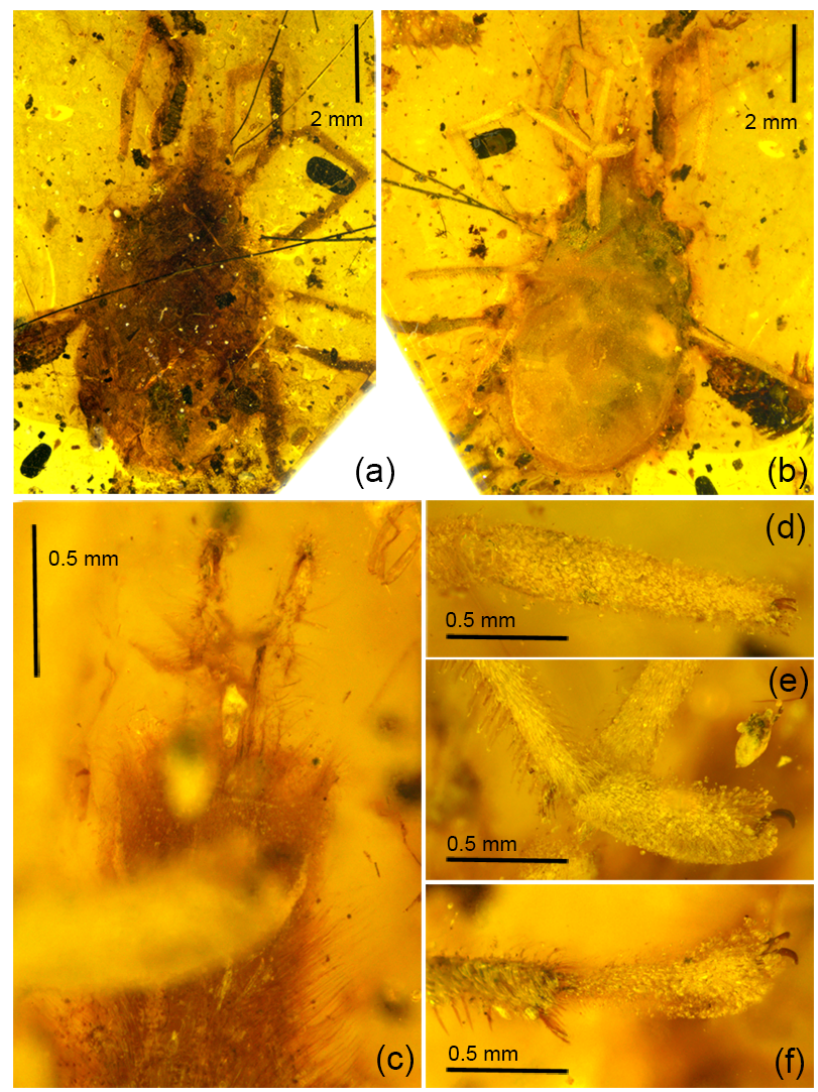

Figure 1. Holotype of Immensmaris chewbaccei gen. et sp. nov. (a) Dorsal overview. (b) Ventral overview. (c) Gnathosoma. (d) Leg I tarsus. (e) Leg II tarsus. (f) Leg III tarsus.

tion, 2018), but is not described here as it is not yet in a public depository.

\subsection{Study methods}

The mite was photographed immersed in water using a Leica microscope running the software Leica Application Suite V.4.5. Image stacks were combined using Helicon Focus 6.7.1 and compiled into the final plate (Fig. 1) using Adobe Photoshop CS5. Drawings (Fig. 2) were prepared with a camera lucida attached to a Leica M205 C stereomicroscope and digitally inked following the methods developed by Coleman (2003) using Adobe Illustrator. All measurements are in micrometres $(\mu \mathrm{m})$.

\subsection{Burmese amber}

Modern collections of Burmese amber originate from the Hukawng Valley in northern Myanmar and are dated to the Late Cretaceous (Cenomanian). Shi et al. (2012) offered an age constraint of ca. $99 \mathrm{Ma}$ based on zircon dating and an absolute date of ca. $100 \mathrm{Ma}$ has been suggested (Smith and Ross, 2018) based on evidence from bored bi- valves that there has been relatively little reworking of the amber into its host sediments. Burmese amber is thought to represent a tropical forest environment (Grimaldi et al., 2002). For a recent overview of the geological setting see Selden and Ren (2017), and references therein. Burmese amber yields representatives of all living arachnid orders, including 15 provisionally identified acariform mite families (e.g. Rasnitsyn et al., 2016: Supplementary data). Burmese parasitengonids were recently documented by Konikiewicz and Mąkol (2018), but only two non-parasitengone species, respectively in Cheyletidae and Resinacaridae, have been formally described (Cockerell, 1917; Khaustov and Poinar Jr., 2010).

\section{Systematic paleontology}

\author{
Superorder Acariformes Zakhvatkin, 1952 \\ Suborder Prostigmata Kramer, 1877 \\ Cohort Parasitengona Oudemans, 1909 \\ Superfamily Erythraeoidea \\ Robineau-Desvoidy, 1828 \\ Family Smarididae Vitzthum, 1929 \\ Genus Immensmaris gen. nov. \\ (urn:lsid:zoobank.org:act:6348E5D1-6BE5-425F- \\ 8DA2-46CEDF7D04F0, 18 October 2018)
}

Content: Type and only species is Immensmaris chewbaccei gen. et sp. nov.

Diagnosis: Active post-larval form: extremely large smaridid mite, with idiosoma exceeding $8 \mathrm{~mm}$. Armilla is present; chelicerae and palps are retractable. Idiosomal setae [?] is uniform in shape, slender, unmodified, forming relatively dense setation cover (visible on lateral margins and ventral side of body); ventral setae are smaller than dorsal ones. Legs I and II are slightly longer than idiosoma, with dense setation. Tarsus I is indistinctly shorter than tibia I. Larva is unknown.

Etymology: From the Latin immensus (immense) plus the extant genus Smaris.

Immensmaris chewbaccei gen. et sp. nov. (urn:Isid:zoobank.org:act:60C05668-CC7E-44A8B02B-C5634FA984A8, 18 October 2018)

Figs. 1-2.

Diagnosis: As for the genus.

Etymology: After the large Star Wars character Chewbacca.

Holotype: Museum für Naturkunde Berlin (MB.A. 4267); 

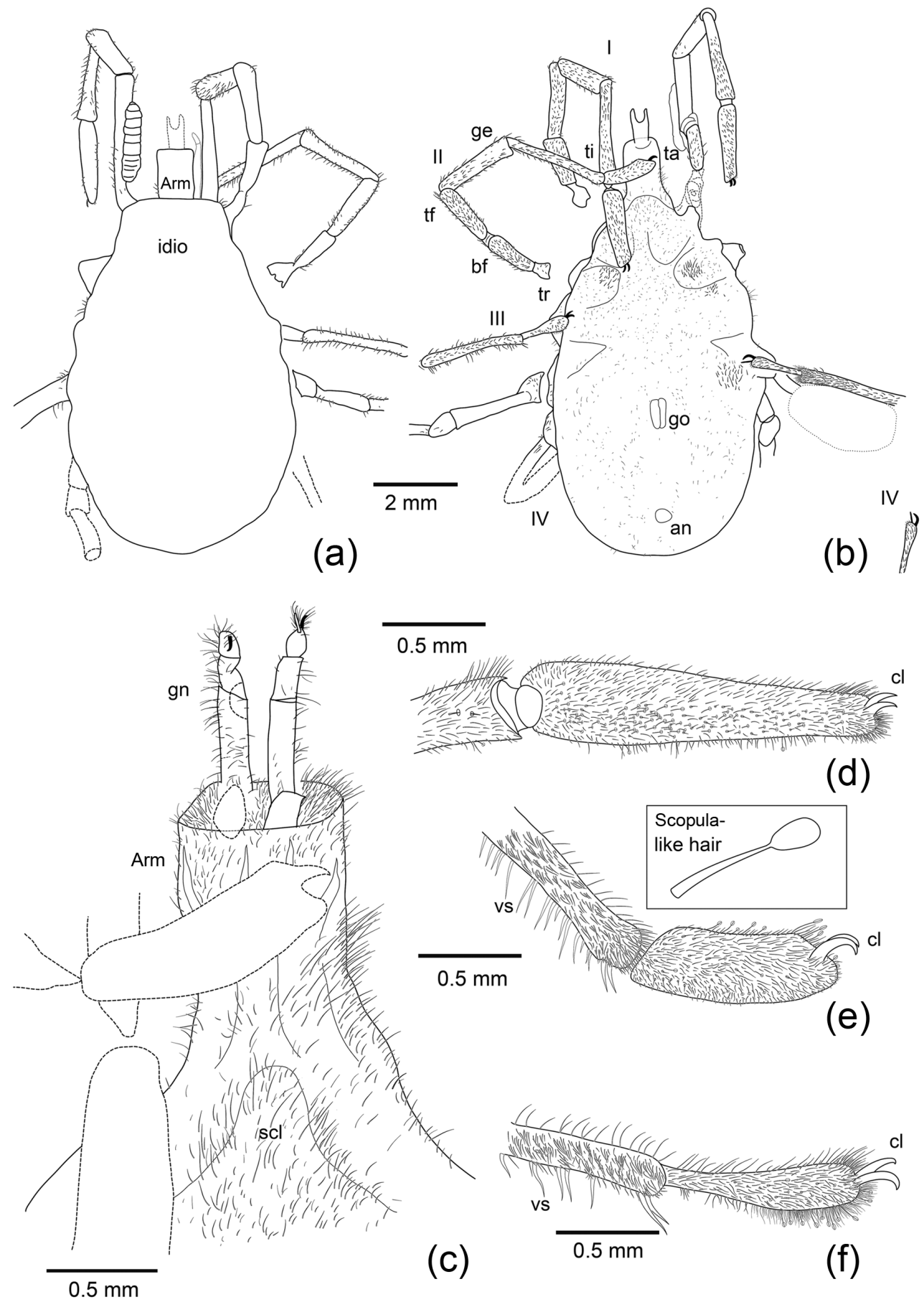

Figure 2. Interpretative drawings of the specimen shown in Fig. 1. Legs are numbered from I-IV. Abbreviations: an is anus, arm is armilla, bf is basifemur, ge is genu, cl is tarsal claws, gn is gnathosoma, go is genital opening, idio is idiosoma, pp is pedipalp, ta is tarsus, tf is telofemur, ti is tibia, tr is trochanter, vs is ventral tibial spines.

ex coll. P. Müller, no. BUB305.

Formation and age: Burmese amber, Hukawng Valley, Myanmar. Late Cretaceous (Cenomanian).
Description: Postlarval instar (probably adult) has a maximum length (gnathosoma and idiosoma) of 10270 ; gnathosoma length is 1970; idiosoma length is 8300; maximum idiosoma width is 4640 . Gnathosoma is ensheathed by basal, largely cylindrical and highly setose armilla (length 
1080, width 750) and is slightly wider proximally and open and ring-like distally. Chelicerae and palps extend down into enveloping armilla. Chelicerae styliform have a maximum preserved length (extending beyond armilla) of 700. Palps are five-segmented, delicate, slender and setose. Odontus (?) is simple, similar in length to palp tarsus. Maximum preserved length of palps (including five free segments extending beyond armilla) is 880 . Idiosoma suboval narrows anteriorly towards gnathosoma and is broadly rounded posteriorly. Dorsum is largely obscure. Venter has a light covering of short (non-pennate) setae; bushels of more prominent setae are on coxae II. Tongue-shaped structure (perhaps denoting better-sclerotized area/sclerite) is narrowed anteriorly, reaching base of armilla and extending posteriorly, and is present on idiosoma venter. Slit-like genital opening has a length of 670 , with paired surrounding sclerites positioned on midline between leg IV coxae. Anus subcircular has a length of 300 , a width of 360 and is positioned towards posterior end of venter.

Legs are moderately long and slender; coxae are subquadrate to subtriangular. Legs I-II are preserved in their entirety, leg III is partially preserved, leg IV incomplete. Lengths of individual articles as follows. Leg I: trochanter is 550 , basifemur is 1120 , telofemur is 1630 , genu is ca. 1200 , tibia is ca. 2200, tarsus is 1760 . Total length (excluding coxa) is ca. 8460 . Leg II: trochanter is 360 , basifemur is 1210 , telofemur is 1480 , genu is 1880 , tibia is 2420 , tarsus is 1210. Total length (excluding coxa) ca. 8560. Leg III: trochanter is 450 , basifemur is ca. 1800 , telofemur and genu are equivocal, tibia is 2360 , tarsus is ca. 1200 . Leg IV: tarsus are 1080. Tibiae expand slightly towards distal end. Tarsi is bluntly rounded; tarsus I appears slightly flatter and is longer relative to tibia, compared to legs II-III, where tarsus is rounder and proportionally shorter relative to tibia. All legs are densely covered with short, unmodified nude setae (i.e. without barbs), but some tarsal setae had expanded and globose at the tip form dense scopulae at distal ends of legs. Tibia II and III have several thicker ventral spines, the latter being less numerous and distinctly longer than other setae forming dense setation cover, and have a robust pair of ventral spines near distal margin. Tarsi of all legs terminate in a pair of robust, curved and smooth (i.e. non-fimbriate) claws; those of leg I are smaller than those of legs II-IV.

Remarks: The habitus is inconsistent with the densely setose body of a velvet mite (Trombidiidae) and is obviously more reminiscent of Erythraeoidea, in particular the disposition of the legs. The chelicerae are largely obscured, but the presence of a distinct armilla (Fig. 2c), which envelops the chelicerae and palps, provides evidence for a retractable gnathosoma which is typical for Smarididae. The general morphology with relatively long legs is similar to, for example, Clavismaris conifera Southcott, 1963 (Southcott, 1963). On the other hand, the presence of strong ventral spines on the distal part of tibiae II and III has not been hitherto reported for Smarididae but is reminiscent of some modern species of Erythraeidae. The equivocal nature of the dorsal idiosoma (Figs. 1a, 2a) means we cannot ascertain some diagnostic features which play a crucial role in smaridid taxonomy and determining the subfamily of the newly erected taxon. These include the presence/shape of the crista metopica and/or scutum and the structure of the eyes.

However, the extreme size of this specimen, not hitherto reported from any other extinct or extant smaridid genus, as well as the dense setation on the legs, justifies erecting a new genus. The overall idiosoma shape, as well as the general structure of the legs resembles the condition, e.g. in Smaris Latreille, 1796 or Sphaerotarsus Womersley, 1936 (Womersley and Southcott, 1941; Southcott, 1960). The presence of elongate setae on the dorsal idiosoma, close to the lateral margins of the body, and thus likely upon the entire idiosoma dorsum too, indicates some congruence with extant Smaridinae - namely Calorema Southcott, 1962, Fessonia von Heyden, 1826 Kraussiana Southcott, 1961 and Smaris. In contrast to Hirstiosomatinae, they reported more elongate setae dorsally. A dark, regular shadow on the dorsal side of the idiosoma may denote a pear-shaped scutum, which would be typical for Smaris but is absent in Sphaerotarsus.

\section{Discussion}

\subsection{Giant mites}

Immensmaris chewbaccei gen et sp. nov. is the largest unequivocal fossil mite ever recorded and mites in general seem to have been small throughout their geological history; see Sidorchuk (2018) for a review. Gourret (1887) described two extinct Trombidites from Eocene shales at Aix-en-Provence in France, one of which, Pseudopachygnathus maculatus Gourret, 1887, was given as being about a centimetre long. This record is problematic; see also Sidorchuk (2018). The genus is clearly derived from Pachygnathus Dugès, 1834, which now belongs to Alycidae, a family of tiny (ca. 150$200 \mu \mathrm{m})$ endeostigmatid mites. While clearly an arachnid with long, setose limbs, Gourret's accompanying drawing does not allow us to confidently place this fossil in any particular mite family and even lacks unequivocal diagnostic mite characters like a gnathosoma. Pararainbowia martilli Dunlop, 2007 from the Brazilian Crato Formation (Dunlop, 2007) is clearly an erythraeid, a little less than $5 \mathrm{~mm}$ in length, and another rare example of an acariform mite preserved in a shale.

Most Acariformes have been recovered from Mesozoic and Cenozoic ambers. The largest, named Erythraeidae, is from Burmese amber and $2.44 \mathrm{~mm}$ in length (without the gnathosoma) Konikiewicz and Mąkol, 2018), although an unnamed Smaridinae attained $3.89 \mathrm{~mm}$ and an unnamed Trombidioidea $3.59 \mathrm{~mm}$. Juvenile mites, less than $0.5 \mathrm{~mm}$ and assigned to Leptus sp. (Erythraeidae), have also been 
recorded from the Spanish Cretaceous San Just amber (Arillo et al., 2018). All Cenozoic amber records are less than $2 \mathrm{~mm}$. Koch and Berendt's (1854) monograph on Baltic amber gave measurements using the obsolete term "lines". Their largest mite was a trombidiid almost $3 / 4$ of a line long. Depending on whether this represents $1 / 10$ or $1 / 12$ of an inch, this translates to about $1.6-1.9 \mathrm{~mm}$. More recent examples of fossil Acariformes more than a millimetre long include a $1.13 \mathrm{~mm}$ rhagidiid from Baltic amber (Judson and Wunderlich, 2003) and smaridids in Baltic and Bitterfeld amber with idiosoma lengths up to $1.49 \mathrm{~mm}$ (Bartel et al., 2015).

\subsection{Palaeoecology}

Immensmaris chewbaccei also appears to be the largest erythraeoid mite ever recorded, surpassing even the modern Australian species in size (Southcott, 1961). It demonstrates that there was a clade of giant, presumably now extinct, smaridid (or erythraeoid) mites in the Late Cretaceous of southeastern Asia, and adds to a growing picture of fascinating and often remarkable arachnid fauna preserved in Burmese amber (Selden and Ren, 2017). Deutonymphs and adult smaridids are generalist predators on small arthropods, especially their eggs (Wohltmann, 2010), but have a parasitic larval instar, which usually attacks other arthropods. We can only speculate on the host(s) of the giant mite's larvae. Modern smaridid species have been recorded parasitising Psocoptera (book- or barklice); see e.g. Womersley and Southcott (1941), but in general knowledge of the host spectrum of extant Smarididae is still very scarce.

Some modern erythraeoids are arboreal (Southcott, 1961; Walter, 1995) and the scopula-like hairs on the leg tarsi of the new fossil (Fig. 2e-f) may be adaptations for climbing and indicate a similar ecology. Scopulate erythraeoid tarsi were figured by Southcott (1991) and others, while Wolff and Gorb (2016) offered an overview of adhesive hairs in trombidiform mites (and other arachnids) in general. Southcott (1946) reported that two of the larger Australian erythraeids (Erythrites reginae, Rainbowia imperator) are nocturnal, but spend the day under the bark of eucalyptus trees. If the large fossil described here was also associated with tree habitats - which is in any case usually true for animals preserved in amber - this might explain how it became trapped in resin flowing down tree trunks.

Data availability. All material included in the paper is accessible in the listed museum and all data are included in the descriptions.

Author contributions. JAD and JM primarily wrote the paper and are responsible for the description and systematic placement. KF primarily prepared the photographs and drawings.
Competing interests. The authors declare that they have no conflict of interest.

Acknowledgements. We thank Patrick Müller for the initial access to material from his collection, Oliver Coleman for advice on digital inking and Ekaterina Sidorchuk for drawing our attention to a second fossil and for access to her forthcoming manuscript of body size in fossil mites. We also thank Andreas Wohltmann and an anonymous reviewer for helpful comments on a previous version of the typescript.

Edited by: Florian Witzmann

Reviewed by: Andreas Wohltmann and one anonymous referee

\section{References}

Arillo, A., Blagoderov, V. and Peñalver, E.: Early Cretaceous parasitism in amber: A new species of Burmazelmira fly (Diptera: Archizelmiridae) parasitized by a Leptus sp. mite (Acari, Erythraeidae), Cret. Res., 86, 24-32, 2018.

Bartel, C., Konikiewicz, M., Mąkol, J., Wohltmann, A., and Dunlop, J. A.: Smaridid mites in Baltic and Bitterfeld amber, with notes on the fossil record of terrestrial Parasitengona (Trombidiformes: Prostigmata), Ann. Zool., 65, 641-659, 2015.

Cockerell, T. D. A.: Arthropods in Burmese amber, Psyche, 24, 4045, 1917.

Coleman, C. O.: "Digital inking": How to make perfect line drawings on computers, Org. Div. Evol., 3 (Electr. Suppl. 14), 1-14, 2003.

Dunlop, J. A.: A large parasitengonid mite (Acari, Erythraeoidea) from the Early Cretaceous Crato Formation of Brazil, Foss. Rec., 10, 91-98, https://doi.org/10.1002/mmng.200700001, 2007.

Gourret, P.: Recherches sur les Arachnides tertiaires d'Aix en Provence, Rec. Zool. Suisse, 4, 431-496, 1887.

Grimaldi, D., Engel, M. S., and Nascimbene, P.: Fossiliferous Cretaceous amber from Burma (Myanmar): its rediscovery, biotic diversity and paleontological significance, Am. Mus. Novit., 3361, 1-71, 2002.

Hirst, S.: On some new Australian mites of the families Trombidiidae and Erythraeidae, Ann. Mag. Nat. Hist., 10, 563-571, 1928a.

Hirst, S: On some Australian species of Trombidiidae, Proc. Zool. Soc. Lond., 67, 1021-1034, 1928b.

Judson, M. and Wunderlich, J.: Rhagidiidae (Acari, Eupodoidea) from Baltic amber, Acta Zool. Cracov., 46 (suppl.-Fossil Insects), 147-152, 2003.

Khaustov, A. A. and Poinar Jr., G. O.: Protoresinacarus brevipedis gen. n., sp. n. from Early Cretaceous Burmese amber: the first fossil record of mites of the family Resinacaridae (Acari: Heterostigmata: Pyemotoidea), Hist. Biol., 23, 219-222, 2010.

Koch, C. L. and Berendt, G. C.: Die im Bernstein befindlichen Myriapoden, Arachniden und Apteren der Vorwelt, in: Die in Bernstein befindlichen organischen Reste der Vorwelt gesammelt in Verbindung mit mehreren bearbeitetet und herausgegeben 1, edited by: Berendt, G. C., Berlin, Nicolai, 124 pp., 1854.

Konikiewicz, M. and Mąkol, J.: Insight into fossil fauna of terrestrial Parasitengona mites (Trombidiformes: Prostigmata) - the 
first representatives of Erythraeina Welbourn, 1991 and Trombidiina Welbourn, 1991 in Burmese amber, Cret. Res., 89, 60-74, 2018.

Linnaeus, C.: Systema naturae, 12th ed., Stockholm, 533-1327, 1767.

Rainbow, W. J.: A synopsis of Australian Acarina, Rec. Aust. Mus. 6, 145-193, 1906.

Rasnitsyn, A. P., Bashkuev, A. S., Kopylov, D. S., Lukashevich, E. D., Ponomarenko, A. G., Popov, Y. A., Rasnitsyn, D. A., Rhzhkova, O. V., Sidorchuk, E. A., Sukatsheva, I. D., and Vorontsov, D. D.: Sequence and scale of changes in the terrestrial biota during the Cretaceous (based on materials from fossil resins), Cret. Res., 61, 234-255, 2016.

Selden, P. A. and Ren, D.: A review of Burmese amber arachnids, J. Arachnol., 45, 324-343, 2017.

Shi, G.-H., Grimaldi, D. A., Harlow, G. E., Wang, J., Yang, M.-C., Lei, W.-Y., Li, Q., and Li, X.-H.: Age constraints on Burmese amber based on U-Pb dating of zircons, Cret. Res., 37, 155-163, 2012.

Sidorchuk, E. A.: Mites as fossils: forever small?, Int. J. Acarol., in press, 2018.

Smith, R. D. A. and Ross, A. J.: Amberground pholadid bivalve borings and inclusions in Burmese amber: implications for proximity of resin producing forests to brackish waters, and the age of the amber, Earth Environ Sci. Trans. Roy. Soc. Edinburgh, 107, 239-247, 2018.

Southcott, R. V.: Studies on Australian Erythraeidae (Acarina), Proc. Linn. Soc. New South Wales, 71, 6-48, 1946.

Southcott, R. V.: Notes on the genus Sphaerotarsus (Acarina, Trombidiidae), Trans. Roy. Soc. South Aust., 83, 149-161, 1960.
Southcott, R. V.: Studies on the systematics and biology of the Erythraeoidea (Acarina) with a critical revision of the genera and subfamilies, Aust. J. Zool., 9, 367-610, 1961.

Southcott, R. V.: The Smarididae (Acarina) of North and Central America and some other countries, Trans. Roy. Soc. South Aust., 86, 159-245, 1963.

Southcott, R. V.: A further revision of Charletonia (Acarina : Erythraeidae) based on larvae, protonymphs and deutonymphs, Invertebr. Taxon., 5, 61-131, 1991.

Thor, S. and Willmann, C.: Trombidiidae, Das Tierreich, 71b, 187$541,1947$.

Walter, D. E.: Dancing on the head of a pin: mites in the rainforest canopy, Rec. West. Aust. Mus., Suppl., 52, 49-53, 1995.

Walter, D. E., Lindquist, E. E., Smith, I. M., Cook, D. R., and Krantz, G. W.: Order Trombidiformes, in: A manual of Acarology 3rd Edition, edited by: Krantz, G. W. and Walter, D. E., Texas Tech University Press, Lubbock, 2009.

Wohltmann, A.: Notes on the taxonomy and biology of Smarididae (Acari: Prostigmata: Parasitengona), Ann. Zool., 60, 355-381, 2010.

Wolff, J. O. and Gorb, S. N.: Attachment structures and adhesive secretions in arachnids, Springer International Publishing Switzerland, 184 pp., 2016.

Womersley, H: A revision of the trombid and erythraeid mites of Australia with descriptions of new genera and species, Rec. South Aust. Mus., 5, 179-254, 1934.

Womersley, H. and Southcott, R. V.: Notes on the Smarididae (Acarina) of Australia and New Zealand, Trans Roy. Soc. South Aust., 65, 61-78, 1941. 